\title{
Faktor Risiko dan Luaran Fungsi Hati pada Asfiksia Neonatus di Unit Perawatan Intensif Neonatus [UPIN] RSUP Sanglah Denpasar
}

\author{
I Wayan Dharma Artana \\ Bagian Ilmu Kesehatan Anak Fakultas Kedokteran Universitas Udayana RSUP Sanglah, Denpasar
}

\begin{abstract}
Latar belakang. Asfiksia neonatus menyebabkan disfungsi organ, termasuk hati sebagai salah satu organ yang dikorbankan akan mengalami cedera karena proses asfiksia.

Tujuan. Mengetahui dan membandingkan luaran fungsi hati pada asfiksia neonatus dan mengetahui faktor risiko kejadian asfiksia.

Metode. Penelitian dengan rancangan potong lintang, subyek dipilih dengan cara non random sampling, yaitu consecutive sampling, sejak bulan Juni sampai Desember 2010. Subyek penelitian 46 neonatus asfiksia dan 60 kontrol. Hubungan antara derajat asfiksia dengan parameter fungsi hati dilakukan dengan analisis of varian (ANOVA).

Hasil. Dari 46 neonatus asfiksia, derajat ringan 21 (19,8\%), derajat sedang 11 (10,4\%), derajat berat 14 $(13,2 \%)$. Terdapat perbedaan yang signifikan antara kelompok asfiksia dengan kontrol terhadap enzim serum glutamic oxaloacetic transaminase (SGOT), serum glutamic pyruvic transaminase (SGPT), Prothrombin time (PT) dan International normalised ratio $(\mathrm{INR})(\mathrm{p}<0,001)$. Faktor risiko terhadap kejadian asfiksia adalah umur kehamilan $(\mathrm{p}<0,013)$ dan berat badan lahir $(\mathrm{p}<0,001)$.

Kesimpulan.Asfiksia neonatus menyebabkan luaran SGOT, SGPT lebih tinggi dibandingkan kontrol. Nilai INR dan PT juga dipengaruhi oleh asfiksia neonatus. Sari Pediatri 2012;14(4):260-4.
\end{abstract}

Kata kunci: asfiksia neonatus, fungsi hati

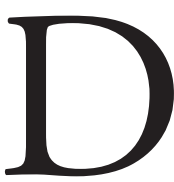

efinisi klinis asfiksia adalah janin atau neonatus harus menderita hipoksia. Manifestasi awal hipoksemia menggambarkan konsentrasi oksigen rendah

Alamat korespondensi:

Dr. I Wayan Dharma Artana, Sp.A. Bagian Ilmu Kesehatan Anak, Fakultas Kedokteran Universitas Udayana, RSUP Sanglah Denpasar. Jl. Pulau Nias 80114. Telp/Fax. (0361) 244038 /(0361) 257387, E-mail: dharma.artana@yahoo.co.id dalam darah. Sebaliknya, hipoksia adalah kondisi oksigenasi di jaringan yang rendah pada fase lanjutan. Hiperkapnia, konsentrasi karbondioksida tinggi mencerminkan peningkatan produksi karbondioksida atau pengurangan ventilasi paru-paru atau pertukaran gas di plasenta. Hasil dari kondisi tersebut adalah asidosis metabolik yang signifikan. ${ }^{1}$

World Health Organization (WHO) menyatakan 23\% dari 4 juta kematian bayi setiap tahun karena asfiksia. Kelangsungan hidup neonatus sangat 
dipengaruhi oleh kejadian asfiksia perinatal dengan efek pada sistem organ yang berbeda. ${ }^{2-4}$

Asfiksia pada neonatus, keadaan awal terjadi depresi dari sistem kardiovaskular, kemudian menyebabkan disfungsi organ lain, syok dengan curah jantung berkurang, hipotensi sistemik, dan hipertensi paru. ${ }^{1,5}$ Kelanjutan asfiksia akhirnya semua sistem organ terkena dampak dekompensasi. Hati sebagai salah satu organ yang dikorbankan akan mengalami cedera karena proses asfiksia. ${ }^{6}$ Riset dasar kesehatan tahun $2007,{ }^{7}$ penyebab utama kematian perinatal di Indonesia adalah gangguan pernapasan $(35,9 \%)$ termasuk asfiksia. Berdasarkan latar belakang masalah tersebut maka dirumuskan, bagaimana luaran fungsi hati pasien asfiksia neonatus yang lahir di ruang bersalin RSUP Sanglah Denpasar, serta apa saja yang menjadi faktor risiko terhadap kejadian asfiksia neonatus?

Penelitian bertujuan untuk mengetahui dan membandingkan luaran fungsi hati pada asfiksia neonatus serta faktor risiko kejadian asfiksia neonatus.

\section{Metode}

Penelitian potong lintang, penilaian terhadap variabel dependen yaitu asfiksia saat subyek lahir diruang bersalin RSUP Sanglah, Denpasar dan data diambil berdasarkan dari catatan medis subyek di ruang rawat gabung ibu-bayi dan di unit perawatan intensif neonatus (UPIN). Subyek dipilih secara non random sampling yaitu consecutive sampling. Subyek terpilih adalah semua subyek yang memenuhi kriteria inklusi, yaitu pasien lahir di ruang bersalin RSUP Sanglah Denpasar, usia kurang dari 12 jam, setuju ikut serta dalam penelitian setelah diberikan penjelasan dan menandatangani informed consent. Kriteria eksklusi adalah neonatus dengan kelainan kongenital berat dan berat badan lahir kurang dari 1000 gram. Penilaian dan keterangan kelaikan etik penelitian diberikan oleh Komisi Etika Penelitian Fakultas Kedokteran Universitas Udayana/Rumah Sakit Umum Pusat Sanglah, Denpasar.

Sejumlah 46 subyek neonatus dengan asfiksia, dilakukan perawatan sesuai dengan standar terapi ${ }^{8}$ dilakukan pemeriksaan sampel darah untuk analisis kadar serum transaminase (SGOT/SGPT), albumin serum, PT, dan INR saat usia kurang dari 12 jam setelah lahir. Pada kelompok kontrol, yaitu neonatus tanpa asfiksia dilakukan pemeriksaan sampel darah yang sama seperti pada kelompok dengan asfiksia. Selanjutnya dilakukan analisis perbandingan terhadap luaran asfiksia yang telah terjadi. Data dikumpulkan berupa nama, nomer rekam medis, jenis kelamin, umur, diagnosis, analisis serum SGOT, SGPT, albumin, dan fungsi pembekuan darah PT serta INR. Observasi pada kedua kelompok dilakukan saat diruang persalinan sampai subyek dipindahkan ke UPIN atau ruang rawat gabung ibu dan bayi.

Asfiksia neonatus adalah kegagalan napas secara spontan dan teratur pada saat lahir atau beberapa saat setelah lahir yang ditandai dengan hipoksemia, hiperkarbia, dan asidosis. ${ }^{9,10}$ Ditentukan dari hasil penilaian skor APGAR, diklasifikasikan dalam tiga kategori, yaitu asfiksia berat jika nilai total APGAR skor $<3$, asfiksia sedang jika APGAR skor 3-4, asfiksia ringan jika APGAR skor 5-6 dan tanpa asfiksia jika nilai APGAR skor $\geq 7 .{ }^{11}$

Perhitungan analisis untuk mencari hubungan antara faktor risiko dengan kejadian dan derajat asfiksia, dilakukan analisis multivariat dengan regresi logistik. Hubungan antara derajat asfiksia dengan parameter fungsi hati (kadar SGOT, SGPT, albumin, PT, dan INR) dilakukan analisis of varian (ANOVA).

\section{Hasil}

Selama periode penelitian dimulai pada bulan Juni 2010 sampai Desember 2010, terdapat 106 neonatus, 61 subyek dengan asfiksia neonatus dirawat di UPIN RSUP Sanglah, Denpasar. Sebelas subyek dieksklusi karena didapatkan kelainan kongenital, 4 subyek menolak berpartisipasi, hanya 46 subyek neonatus dengan asfiksia yang diikutsertakan dalam penelitian. Subyek yang dianalisis 46 asfiksia dan 60 kontrol.

Total subyek selama periode penelitian, 49 (46,2\%) laki-laki dan $57(53,8)$ perempuan, sedangkan umur $<32$ minggu $9(8,5 \%)$ neonatus, di antara umur 32 sampai dengan kurang 37 minggu 17 (17\%), dan berumur 37 minggu atau lebih, 80 (75,5\%). Lebih dari separuh subyek penelitian menggunakan metode persalinan normal pervaginam, yaitu $65(61,3 \%)$, section cesaria $32(30,2 \%)$, dan bantuan alat forceps atau vacuum 7 (6,6\%), serta $2(1,9 \%)$ dengan metode assisted breech. Berat lahir sebagian besar di atas 2500 gram, $83(78,3 \%)$ neonatus, di antara 1500 sampai dengan 2500 gram 19 (17,9\%), dan 4 (3,8\%) dengan 
berat lahir dalam rentang 1000 gram sampai dengan kurang dari 1500 gram. Empat puluh enam neonatus asfiksia dengan derajat ringan $21(19,8 \%)$, derajat sedang $11(10,4 \%)$, dan derajat berat $14(13,2 \%)$. Enam puluh kelompok neonatus tanpa asfiksia sebagai kontrol (Tabel 1).

Riwayat paritas ibu $\leq 2$ kali melahirkan didapat pada $53(50 \%)$ neonatus dan $>2$ kali melahirkan $50 \%$. Usia saat ibu melahirkan $14(13,2 \%)$ neonatus memiliki ibu dengan usia $<20$ tahun saat melahirkan, $73(68,9 \%)$ dengan usia ibu mulai usia 20 tahun sampai dengan kurang 35 tahun. Usia ibu $\geq 35$ tahun saat melahirkan 19 (17,9\%). Nilai kadar serum SGOT dengan rerata (SD) 35,92 iu/l $(8,09)$. Nilai kadar

Tabel 1. Karakteristik populasi penelitian

\begin{tabular}{|c|c|c|}
\hline \multirow{2}{*}{$\begin{array}{l}\text { Variabel } \\
\text { Jenis kelamin (\%) }\end{array}$} & \multicolumn{2}{|c|}{ Jumlah } \\
\hline & & \\
\hline Laki-laki & 49 & $(46,2)$ \\
\hline Perempuan & 57 & $(53,8)$ \\
\hline \multicolumn{3}{|l|}{ Umur kehamilan (minggu, \%) } \\
\hline$<32$ & 9 & $(8,5)$ \\
\hline $32-<37$ & 17 & $(17,0)$ \\
\hline$\geq 37$ & 80 & $(75,5)$ \\
\hline \multicolumn{3}{|l|}{ Metode persalinan (\%) } \\
\hline Normal pervaginam & 65 & $(61,3)$ \\
\hline Sectio cesaria & 32 & $(30,2)$ \\
\hline Vacuum dan forceps & 7 & $(6,6)$ \\
\hline Assisted breech & 2 & $(1,9)$ \\
\hline \multicolumn{3}{|l|}{ Berat badan lahir, (gram (\%)) } \\
\hline $1000-<1500$ & 4 & $(3,8)$ \\
\hline $1500-<2500$ & 19 & $(17,9)$ \\
\hline$\geq 2500$ & 83 & $(78,3)$ \\
\hline \multicolumn{3}{|l|}{ Derajat asfiksia (\%) } \\
\hline Ringan & 21 & $(19,8)$ \\
\hline Sedang & 11 & $(10,4)$ \\
\hline Berat & 14 & $(13,2)$ \\
\hline Kontrol (tidak asfiksia) & 60 & $(56,6)$ \\
\hline \multicolumn{3}{|l|}{ Paritas (\%) } \\
\hline$\leq 2 \mathrm{kali}$ & 53 & $(50,0)$ \\
\hline$>2$ kali & 53 & $(50,0)$ \\
\hline \multicolumn{3}{|l|}{ Usia ibu saat melahirkan } \\
\hline$<20$ tahun $(\%)$ & 14 & $(13,2)$ \\
\hline $20-35$ tahun $(\%)$ & 73 & $(68,9)$ \\
\hline$\geq 35$ tahun $(\%)$ & 19 & $(17,9)$ \\
\hline Kadar serum SGOT (iu/l, Rerata SD) & 35,92 & $(8,09)$ \\
\hline Kadar serum SGPT (iu/l, Rerata SD) & 26,21 & $(6,15)$ \\
\hline Kadar serum albumin (gr/dl, Rerata SD) & 3,19 & $(0,55)$ \\
\hline INR (Rerata SD) & 1,16 & $(0,26)$ \\
\hline Prothrombin time (detik, Rerata SD) & 15,05 & $(3,66)$ \\
\hline
\end{tabular}

serum SGPT dengan rerata (SD) 26,21 iu/l $(6,15)$. Nilai kadar serum albumin dengan rerata (SD) 3,19 $\mathrm{gr} / \mathrm{dl}(0,55)$.

Faktor-faktor risiko terhadap kejadian asfiksia, secara statistik yang bermakna adalah umur kehamilan $(\mathrm{p}=0,013)$ dan berat badan lahir $(\mathrm{p}<0,001)($ Tabel 2$)$.

Terdapat perbedaan bermakna antara kelompok asfiksia dengan kontrol terhadap serum transaminase, selain itu enzim SGOT dan SGPT berbeda bermakna antar kelompok derajat asfiksia. Begitu pula dengan nilai INR dan PT, didapatkan perbedaan secara bermakna (Tabel 3).

\section{Pembahasan}

Kami menemukan hasil yang konsisten dengan penelitian Lee $\mathrm{dkk},{ }^{5}$ prematuritas memiliki risiko yang lebih besar terhadap kematian akibat asfiksia neonatus. Risiko tersebut meningkat 1,61 kali lipat pada usia kehamilan 34-37 minggu dan meningkat 14,33 kali lipat pada usia kehamilan <34 minggu. Begitu pula hasil studi kasus-kontrol yang dilakukan secara retrospektif oleh Oswyn dkk, ${ }^{13}$ menyatakan bahwa bayi preterm dan posterm ditemukan lebih banyak pada kelompok kasus daripada kontrol. Hal tersebut dapat dijelaskan bahwa pada bayi prematur, sawar darah otak sangat imatur sehingga sangat rentan terjadi kerusakan otak akibat dari konsentrasi oksigen yang berkurang di dalam darah dan penurunan perfusi jaringan serta pengaruh inflamasi sitokin. Dengan demikian prematuritas yang disertai asfiksia mempunyai risiko lebih besar terjadi ensepalopati hipoksik iskemik dan perdarahan periventrikular intraventrikular. ${ }^{5}$

Berbeda dengan kadar albumin yang tidak bermakna secara statistik, hal tersebut terjadi kemungkinan karena waktu pengambilan sampel darah kurang dari 12 jam kejadian asfiksia, sehingga kadar albumin belum signifikan turun akibat kerusakan hepar sedangkan SGOT, SGPT, INR, dan PT bereaksi cepat terhadap kejadian asfiksia. Hasil penelitian kami konsisten dengan laporan dari Godambe $^{11}$ di tahun 1997, serum transaminase, INR, dan PT pada neonatus juga dipengaruhi oleh kejadian asfiksia.

Bayi yang lahir dengan keadaan hipoksemia dan disertai kegagalan sirkulasi akan menyebabkan penurunan bermakna aliran darah yang melewati 
I Wayan Dharma Artana: Faktor risiko dan luaran fungsi hati pada asfiksia neonatus

Tabel 2. Hubungan beberapa variabel terhadap derajat asfiksia

\begin{tabular}{|c|c|c|c|c|c|}
\hline \multirow{2}{*}{ Variabel } & \multicolumn{4}{|c|}{ Derajat asfiksia } & \multirow{2}{*}{$\mathrm{p}$} \\
\hline & Ringan & Sedang & Berat & Kontrol & \\
\hline \multicolumn{6}{|l|}{ Jenis kelamin } \\
\hline Laki-laki & 9 & 4 & 7 & 29 & 0,870 \\
\hline Perempuan & 12 & 7 & 7 & 31 & \\
\hline \multicolumn{6}{|c|}{ Umur kehamilan (minggu) } \\
\hline$<32$ & 2 & 1 & 4 & 3 & $0,013^{*}$ \\
\hline $32-<37$ & 3 & 3 & 5 & 6 & \\
\hline$\geq 37$ & 16 & 7 & 5 & 51 & \\
\hline \multicolumn{6}{|l|}{ Metode persalinan } \\
\hline Normal pervaginam & 14 & 6 & 6 & 39 & 0,758 \\
\hline Sectio cesaria & 6 & 4 & 5 & 17 & \\
\hline Vacuum dan forceps & 1 & 1 & 2 & 3 & \\
\hline Assisted breech & - & - & 1 & 1 & \\
\hline \multicolumn{6}{|l|}{ Berat lahir (gram) } \\
\hline $1000-<1500$ & 2 & 1 & - & 2 & $<0,001^{*}$ \\
\hline $1500-<2500$ & 3 & 1 & 9 & 6 & \\
\hline$\geq 2500$ & 16 & 9 & 5 & 52 & \\
\hline \multicolumn{6}{|l|}{ Paritas (kali) } \\
\hline$\leq 2$ & 10 & 4 & 6 & 33 & 0,626 \\
\hline$>2$ & 11 & 7 & 8 & 27 & \\
\hline \multicolumn{6}{|c|}{ Usia ibu saat melahirkan (tahun) } \\
\hline$<20$ & 3 & 2 & 2 & 7 & 0,590 \\
\hline $20-35$ & 14 & 7 & 7 & 45 & \\
\hline$\geq 35$ & 4 & 2 & 5 & 8 & \\
\hline
\end{tabular}

${ }^{*} \mathrm{p}<0.05$

Tabel 3. Hubungan derajat asfiksia dengan parameter biokimia hepar

\begin{tabular}{lccccc}
\hline \multicolumn{1}{c}{$\begin{array}{c}\text { Derajat } \\
\text { asfiksia }\end{array}$} & $\begin{array}{c}\text { Kadar serum } \\
\text { SGOT }(\mathrm{iu} / \mathrm{l}) \\
\text { rerata } \pm \mathrm{SD}\end{array}$ & $\begin{array}{c}\text { Kadar serum } \\
\text { SGPT }(\mathrm{iu} / \mathrm{l}) \\
\text { rerata } \pm \text { SD }\end{array}$ & $\begin{array}{c}\text { Kadar serum } \\
\text { albumin }(\mathrm{gr} / \mathrm{dl}) \\
\text { rerata } \pm \text { SD }\end{array}$ & INR & $\begin{array}{c}\text { Prothrombin } \\
\text { time (detik) } \\
\text { rerata } \pm \text { SD }\end{array}$ \\
\hline Ringan $(\mathrm{n}=21)$ & $16,96 \pm 6,25^{*}$ & $18,74 \pm 9,41^{*}$ & $3,21 \pm 0,51$ & $1,2 \pm 0,25^{*}$ & $14,8 \pm 2,32^{*}$ \\
Sedang $(\mathrm{n}=11)$ & $41,83 \pm 16,74^{*}$ & $26,47 \pm 8,91^{*}$ & $2,99 \pm 0,71$ & $1,2 \pm 0,19^{*}$ & $16,3 \pm 3,26^{*}$ \\
Berat $(\mathrm{n}=14)$ & $136,43 \pm 12,82^{*}$ & $66,23 \pm 13,74^{*}$ & $2,98 \pm 0,68$ & $1,4 \pm 0,37^{*}$ & $19,0 \pm 6,38^{*}$ \\
Kontrol $(\mathrm{n}=60)$ & $18,02 \pm 5,51$ & $19,44 \pm 9,51$ & $3,27 \pm 0,49$ & $1,0 \pm 0,17$ & $13,9 \pm 2,43$ \\
\hline
\end{tabular}

${ }^{*} \mathrm{p}<0,001$

lobus hati kanan sehingga terjadi iskemia dan nekrosis sel hati akut, begitu juga saat terjadi reperfusi jaringan dapat meningkatkan kadar oksigen radikal bebas. Hal tersebut mengakibatkan terjadi penurunan fungsi hati, yaitu peningkatan serum transaminase dan penurunan kapasitas hati terhadap produksi faktor pembekuan. ${ }^{11,14}$ Iskemia dan nekrosis sel hati yang terjadi karena disebabkan oleh asfiksia neonatus merupakan critically ill neonate yang sangat mempengaruhi prognosis. ${ }^{15}$
Pada penelitian kami, asfiksia neonatus memberikan luaran kadar serum transaminase (SGOT dan SGPT) lebih tinggi dibandingkan kelompok kontrol. Selain kadar SGOT dan SGPT, nilai INR dan PT juga memiliki hubungan dengan kejadian asfiksia neonatus. Sedangkan faktor risiko yang ditemukan terhadap kejadian asfiksia neonatus adalah umur kehamilan dan berat badan lahir. Diperlukan penelitian dengan menggunakan subyek lebih besar untuk mengetahui luaran fungsi hati pada asfiksia neonatus dipopulasi. 


\section{Daftar pustaka}

1. Lawn J, Shibuya K, Stein C. No cry at birth: global estimates of intrapartum stillbirths and intrapartumrelated neonatal deaths. Bull World Health Organ 2005;83:409-17.

2. London, Susan Mayor. Communicable disease and neonatal problems are still major killers of children. BMJ 2005;330:748 (2 April), doi:10.1136/bmj.330. 7494.748-g.

3. World Health Organization. The world health report 2005: make every mother and child count. Geneva: WHO; 2005.

4. World Health Organization. Basic newborn resuscitation: a practical guide-revision. Geneva: World Health Organization; 1999. Diunduh dari:www.who.int/ reproductivehealth/publications/newborn_resus_citation/index. html.(Diakses pada tanggal 25 Agustus 2011)

5. Lee A CC, Mulleny LC, Tielsch JM, Katz J, Khatry SK, LeClerq SC, dkk. Risk factors for neonatal mortality due to birth asphyxia in Southern Nepal: A prospective, community-based cohort study. Pediatrics 2008;121:e1381-e90 (doi:10.1542/peds.2007-1966).

6. Haider BA, Bhutta ZA. Birth asphyxia in developing countries: current status and public health implications. Curr Probl Pediatr Adolesc Health Care 2006;36:17888.
7. Badan Penelitian dan Pengembangan Departemen Kesehatan RI. Riset kesehatan dasar 2007. Jakarta: Departemen Kesehatan RI; 2008.h. 278-9.

8. IDAI. Asfiksia Neonatorum. Dalam: Standar pelayanan medis kesehatan anak. Jakarta: Badan Penerbit IDAI; 2004.h.272-6.

9. American Academy of Pediatrics and American College of Obstetricians and Gynaecologists. Care of the neonate. Guidelines for perinatal care. Gilstrap LC, Oh W, penyunting. Elk Grove Village (IL): American Academy of Pediatrics; 2002.h.196-7.

10. McGuire W. Perinatal asphyxia. Clin Evid 2006; $15: 1-2$.

11. SV Godambe, RH Udani, Sushma Malik, BM Kandalkar. Hepatic profile in asphyxia neonatorum. Indian Pediatrics 1997;34:927-30.

12. Emid Gilbert B, Lewis AB. Clinical use of pediatric diagnostic tests. Lippincott Williams \& Wilkins; 2003.h.437-8.

13. Oswyn G, Vince JD, Friesen H. Perinatal asphyxia at Port Moresby general hospital: a study of incidence, risk factors and outcome. PNG Med J 2000;43:110-20.

14. Kiang JL, Tsen KT. Biology of hypoxia. Chinese J Physiology 2006;49:223-33.

15. Tarcan A, Tiker F, Guvenir H, Gurakan B. Hepatic involvement in perinatal asphyxia. J Maternal-Fetal and Neonatal Medicine 2007;20:407-10. 